http://dx.doi.org/10.18778/0208-6107.34.04

\title{
Maciej Hulas
}

\author{
(iD) https://orcid.org/0000-0003-2833-972X \\ John Paul II Catholic University of Lublin \\ Institute of Sociology \\ mhulas@kul.lublin.pl
}

\section{THE NORMATIVITY OF HABERMAS'S PUBLIC SPHERE FROM THE VANTAGE POINT OF ITS EVOLUTION}

\begin{abstract}
The paper argues that the original normativity that provides the basis for Habermas's model of the public sphere remains untouched at its core, despite having undergone some corrective alterations since the time of its first unveiling in the 1960s. This normative core is derived from two individual claims, historically articulated in the eighteenth-century's "golden age" of reason and liberty as both sacred and self-evident: (1) the individual right to an unrestrained disposal of one's private property; and (2) the individual right to formulate one's opinion in the course of public debate. Habermas perceives the public sphere anchored to these two fundamental freedoms/rights as an arena of interactive opinion exchange with the capacity to solidly and reliably generate sound reason and public rationality. Despite its historical and cultural attachments to the bourgeois culture as its classical setting, Habermas's model of the public sphere, due to its universal normativity, maintains its unique character, even if it has been thoroughly reformulated by social theories that run contrary to his original vision of the lifeworld, organized and ruled by autonomous rational individuals.
\end{abstract}

\section{Keywords}

Habermas, public sphere, normativity, civil society, modernity, practical interests

The aim of this paper is to explore the normative foundations of Habermas's public sphere in the context of the vicissitudes they have undergone. The following study is based on a fundamental presupposition, namely that the revisions and corrective alterations that Habermas has introduced throughout the decades into his original concept of the public sphere have not substantially changed the normative foundation of this idea, which remains untouched at its core. Both the initial unveiling of the notion of the public sphere in the early 1960s and the later amendments up to the final one made in the 1990s have invariably drawn on the same cluster of normative resources, which are the individual and 
universal freedoms of a human being, protected by corresponding negative defensive rights. ${ }^{1}$ Habermas sets his concept of the public sphere in universal freedoms and negative rights. ${ }^{2} \mathrm{He}$ is profoundly convinced of their capacity to solidly and reliably generate sound reason and public rationality, regardless of time and circumstances.

The mobilization of ordinary people who had formed the first political public sphere as a grassroots counter-move against the absolutist power, appeared to be a natural self-protective reaction against the official regulation of intellectual, moralistic and critical newspapers that served as milieus of unhindered debate of ordinary people, it was also a nonconformist response of to a state interfering into the individual freedom of labor and commodity exchange. This kind of mobilization would not be possible without critical self-awareness developed previously in debates on culture in the intellectually oriented literary public sphere and without analogous belief in being a collective prime mover - this very belief bolstered up the authority of critical argument. In such a joint union that amalgamates the natural determination and capacity to defend fundamental freedoms (unrestricted ruling over one's own property) with the ordinary people's belief in being a collective prime mover, the originality of Habermas's stance is detectable - he creates a link between them two and joins into one (a) the demands for fundamental freedom/negative defensive rights (self-sufficiency) and (b) the capacity for enduring self-determination (self-rule). In this original combination he goes beyond the traditional dichotomy of liberalism vs republicanism and this dialectical relationship is noticeable in his cooriginality thesis of private and public autonomy.

(1) To analyze the normative layers of Habermas's public sphere with a view to proving its immutability, we need to first outline the specific historical context in which he forged his concept of the public sphere, viewed in social theory thereafter as paradigmatic and an ideal one. We need also to trace the journey that his concept of the public sphere has been one from its first appearance in a form of an early liberal, historical and critical account in the early 1960s, to the most recent unveiling in the 1990s as a component of a democratic state, expounded in a concise systematic language with reference to other invariants which altogether comprise Habermas's unique notion of democracy. (2) The journey in question commences with the scrutiny of the bourgeois public sphere, delineated in his habilitation thesis Strukturwandel der

\footnotetext{
${ }^{1}$ Robert Alexy, A Theory of Constitutional Rights (Oxford: Oxford University Press, [1986] 2010), 167.

2 "The bourgeois public sphere could be understood as the sphere of private individuals assembled into a public body, which almost immediately laid claim to the officially regulated "intellectual newspapers" for use against the public authority itself. In those newspapers, and in moralistic and critical journals, they debated that public authority on the general rules of social intercourse in their fundamentally privatized yet publically relevant sphere of labor and commodity exchange". Jürgen Habermas, "The Public Sphere. An Encyclopedia Article (1964)", transl. Sara Lennox and Frank Lennox, New German Critique, no. 3 (Autumn 1974): 52.
} 
Öffentlichkeit (1962). (3) Soon after its publication, it turned out that the hermeneutical key that unlocks an insight into the very logic of the bourgeois public sphere was to be found elsewhere, in his original thesis on the interdependence between knowledge and human interests, described in Erkenntnis und Interesse (1965/1968). In dealing with the normativity of the public sphere, we need to identify those sections of Erkenntnis und Interesse that converge with the fundamental premises of the public sphere from Strukturwandel der Öffentlichkeit. (4) The first significant indication of the future revisions to Habermas's concept of the public sphere are to be found in his work on the systemic crises in advanced capitalism Legitimationsprobleme im Spätkapitalismus (1973). We need to establish the degree to which the fundamental criteria and premises of his original model can be met and realized in a democratic state of advanced capitalism. (5) To grasp the moment in which the original concept of Habermas's public sphere began to drift away from its first historical-critical account and towards the aforementioned systematic, jurisprudential and statedemocracy oriented explanations, requires touching upon the specificity of the lifeworld organized and ruled by the partial systems within a total social system, as portrayed in Rekonstruktion des historischen Materialismus (1976). (6) In its final stage, Habermas's model of the public sphere appears as the highest authority over decision-making processes in a constitutional democratic state. We need to identify, then, those areas of civil society (Zivilgesellschaft) which maintain the normativity of its initial exposition.

\section{RECASTING THE IDEOLOGICAL IMPASSE AROUND THE PUBLIC SPHERE}

The terms "public sphere" - as a communication arena accessible to all - and "public opinion" - as a common view of people that together constitute a collective singulative ${ }^{3}$ such as nation or civil society - have been a mainstay of modern social theory. However, it was Habermas who first managed to conceptualize them both. Unlike Lippmann, ${ }^{4}$ Dewey, ${ }^{5}$ Schmitt, ${ }^{6}$ Heidegger ${ }^{7}$ Koselleck ${ }^{8}$

\footnotetext{
${ }^{3}$ Shmuel Noah Eisenstadt, "Multiple Modernities," Deadalus 129, no. 1 (2000): 8.

${ }^{4}$ Walter Lippmann, The Phantom Public. The Sequel to „Public Opinion” (New York: The Macmillan Company, 1930), 39.

5 John Dewey, The Public and Its Problems, in The Later Works, 1925-1953, Vol. 2: 1925-1927, ed. J. A. Boydston, B. W. Walsh Introduction J. Gouinlock (Carbondale \& Edwardsville: Southern Illinois University Press, [1927] 1988), 277.

${ }^{6}$ Carl Schmitt, Die geistesgeschichtliche Lage des heutigen Parlamentarismus (Berlin: Duncker und Humbolt, [1923] 1961), 29.

${ }^{7}$ Martin Heidegger, Sein und Zeit, (Tübingen: Max Niemeyer Verlag, [1926] 1967), 167-170.

${ }^{8}$ Reinhart Koselleck, Kritik und Krise. Eine Studie zur Pathogenese der bürgerlichen Welt (Freiburg/München: Suhrkamp [1959] 1973), 93-103.
} 
and Arendt, ${ }^{9}$ Habermas neither perceives nor treats either term as mere variables that are useful for diagnosing civil society's awareness in participating in political decision-making; for demonstrating the decomposition of critical rationality; for pointing to failures in the functioning of state institutions that are supposed to be democratic; or for measuring the human condition, etc. Instead he explores the topics of the public sphere and public opinion through their historicity, normativity, and functionality in the changing conditions of society, the economy, and the state. The academic consensus ${ }^{10}$ regarding his early works on the public sphere ${ }^{11}$ validates the unprecedented character of Habermas's conceptualization of the public sphere and public opinion, which helped him to recast the prevailing pessimism of the debate that had developed over decades and affected how they were perceived up to the 1960s. This pessimism was a product of the masses' increased accessibility to the public sphere that emerged in the nineteenth century. ${ }^{12}$ As a result of this enhanced accessibility, the sublime public rationality - reflected in the Kantian imperative that prompts to utter publicly what one may think of as fragments of universal truth unknown to the rest - began to lose its emancipatory distinctiveness and became associated with the will of the masses which was more susceptible to manipulation and less likely to be the repository of rational and critical judgments. In his concept of the public sphere, Habermas effectively points to the possibilities of how the potentials of the public sphere and public opinion are to be utilized in building up an ideal civil society that is responsible and politically committed.

\footnotetext{
${ }^{9}$ Hannah Arendt, The Human Condition. Introduction by Margaret Canovan (Chicago/London: The University of Chicago Press [1958] 1998), 54f.

${ }^{10}$ See inter alia: Theodor W. Adorno, Meinungsforschung und Öffentlichkeit (1964), Gesammelte Schrifen, Bd 8: Soziologische Schrifen I, ed. R Tiedemann, unter Mitwirkung von G. Adorno, S. BuckMorss, K. Schultz, (Frankfurt/M: Suhrkamp Verlag, [1972] 1990), 532f; Franz Ronneberger, "Organisierte Interessen und öffentliche Meinungsbildung", Soziale Welt, 15. Jahrg., H. 1 (1964): 4046; Peter Häberle, "Öffentlichkeit und Verfassung: Bemerkungen zur 3. Aufl. Von Jürgen Habermas, Strukturwandel der Öffentlichkeit (1968)", Zeitschrift für Politik, Neue Folge, Vol. 16 (1969), No 2, 273-287. See also the polemical works: Oskar Negt, Alexander Kluge, Public Sphere and Experience. Toward an Analysis of the Bourgeois and Proletarian Public Sphere, foreword by M. Hansen, transl. by P. Labanyi, J. O. Daniel, A. Oksiloff, (Minneapolis: The University of Minnesota Press, 1993); Wolfgang Jäger, Öffentlichkeit und Parlamentarismus. Eine Kritik an Jürgen Habermas (Stuttgart: Verlag W. Kohlhammer, 1973).

${ }^{11}$ Jürgen Habermas, Christoph Oehler, Ludwig von Friedeburg, and Friedrich Weltz, Student und Politik. Eine soziologische Untersuchung zum politischen Bewußtsein Frankfurter Studenten (Neuwied: Luchterhand Verlag, [1961] 1969); Jürgen Habermas, Strukturwandel der Öffentlichkeit. Untersuchungen zu einer Kategorie der bürgerlichen Gesellschaft (Neuwied: Luchterhand [1962] 1990); Jürgen Habermas, "Öffentlichkeit," in Staat und Politik. Das Fisher Lexikon, ed. E. Fraenkel and K. D. Bracher (Frankfurt: Fischer Taschenbuch Verlag, [1957] 1976), 220-226.

12 Marek Czyżewski, Öffentliche Kommunikation und Rechtsextremismus (Lódź: Wydawnictwo Uniwersytetu Łódzkiego, 2005), 288-292.
} 
The evocative power of his concept of the public sphere in the 1960s turned out to be a remedy for the political inertia that marked the postwar West German society of the Adenauer era $^{13}$ and soon became the subject matter for surveys and numerous critical studies both in Germany and abroad.

\section{THE MODEL OF THE CLASSICAL BOURGEOIS PUBLIC SPHERE}

Habermas invented his concept of the public sphere by adopting the bourgeois ethos of eighteenth-century England, France, and Germany. In his early works as well as in the later ones Habermas brings up the existence of milieus in which public sphere developed simultaneously with the bourgeois one, namely the plebeian class and a variety of small-scale businessmen groups (counterpublics). ${ }^{14}$ The reason, however, why he excludes them from the process of civic autonomy and public rationality formation is their inability to bring into that process a new quality that might have changed it substantially. As Honneth puts it, plebeian associations were devoid of the Enlightenment progressive self-awareness; their demands were also devoid of universality as they came from existential privation; they generated and inclined to feed on short-term acts of non-conformism such as strike and class struggle. Plebeian groups might have formed their own spheres of public debate similar to the bourgeois one in terms of culture and civility, nevertheless, the problems discussed within them did not seem to have any significant meaning for the whole of society. ${ }^{15}$

In this way, his classical model of the public sphere came into being with the bourgeoisie which emerged at that time as an unique group within Europe, becoming more and more independent and growing in its distinctive position in the world of culture, social labor, and commodity trade. This fusion that has bound the public sphere to the bourgeois ethos soon proved to have ambivalent effects on the whole concept. On the one hand, bourgeois moral codes seemed to be the most suitable means of conveying sound reason and common sense, generated by universal individual values such as life, freedom, and property. No previous age has ever managed to create more favorable conditions in articulating individual freedom as well as fitting thereto negative rights to protect them, compared to the intellectual and societal character of occidental modernity. In those unprecedented conditions of modernity, the public sphere, the free market economy, autonomous society, and participatory democracy had

\footnotetext{
13 "Strukturwandel der Öffentlichkeit" von Jürgen Habermas, Michael Haller im Gespräch mit Hans Ulrich Probst, Radio SRF 2 Kultur, 14. März 2012, 1:39-2:21, 7:30-8:10, 10:16-10:29.

${ }^{14}$ Craig Calhoun, The Roots of Radicalism. Tradition, the Public Sphere, and Early Nineteenth-Century Social Movements, (Chicago: The University of Chicago Press, 2012), 129-134; Craig Calhoun, "The Public Sphere in the Field of Power," Social Science History, 34, no. 3 (Fall 2010): 309f.

${ }^{15}$ Axel Honneth, Das Recht der Freiheit. Grundriß einer demokratischen Sittlichkeit, (Berlin: Suhrkamp Verlag, 2015), 477f.
} 
for the first time achieved their objectified ontological forms ${ }^{16}$. On the other hand, such proximity to the bourgeois ethos left an indelible and ideological mark on the public sphere and public opinion, according to which full civic subjectivity is attainable only in an integral union of two personal statuses: the first of which depends on education (Bildung); the second of which depends on ownership of estate (Besitz). ${ }^{17}$ The bourgeois ethos adopted by Habermas as a pattern and explanation of full public subjectivity has been raised by some of his critics as an argument that challenges the most fundamental tenet of any public sphere, i.e. its uncontrolled openness to an unrestricted number of people willing to join or leave the arenas of public debate unnoticed, anonymously, and informally. ${ }^{18}$ The objections made to the ostensible exclusivity of Habermas's public sphere seem to rest upon questionable factual premises. They draw upon life experiences that differ from those of Habermas's, and they appear to demur at the bourgeois order with its prevailing specific imagining of social roles and functions attributed in the eighteenth-century society to gender, property, and the ability to comprehend. This dissatisfaction with the absence of both plebeian groups and women in the mainstream (bourgeois) public sphere appears to be the consequence of a disapproving outlook on the eighteenthcentury societal conditions seen through the lens of non-alternative equal rights for all, that has been a distinctive mark of the Western world after the cultural revolution of the 1960s. ${ }^{19}$

\footnotetext{
${ }^{16}$ Shmuel Noah Eisenstadt, "Public Spheres and Civil Society in Selected Pre-Modern Societies: Some Comparative Observations," Comparative Sociology 5, no. 1 (2006): 2; Charles Taylor, A Secular Age (Cambridge, MA: The Belknap Press of Harvard University Press, 2007), 159-211.

${ }^{17}$ Habermas, Strukturwandel der Öffentlichkeit, $\$ 4$, 6f. "The fully developed bourgeois public sphere was based on the fictitious identity of the two roles assumed by the privatized individuals who came together to form a public: the role of property owners and the role of human beings pure and simple. This identification of the public of 'property owners' with that of 'common human beings' could be accomplished all the more easily, as the social status of the bourgeois private persons in any event usually combined the characteristic attributes of ownership and education". Citation after the English translation The Structural Transformation of the Public Sphere. An Inquiry into a Category of Bourgeois Society, translated by Thomas Burger with the assistance of Frederick Lawrence (Cambridge MA: The MIT Press [1962] 1991), 56.

${ }^{18}$ Joan Landes, Women and the Public Sphere in the Age of the French Revolution (Ithaca: Cornell University Press, 1988), 7; Amy Allen, "The Public Sphere: Ideology and/or Ideal?," Political Theory 40, no. 6 (December 2012): 822; Marie Fleming, "Women and the 'Public Use of Reason'," Social Theory and Practice 19, no. 1 (Spring 1993): 29, 33, 38, 42f; Nancy Fraser, "Rethinking the Public Sphere," in Habermas and the Public Sphere, ed. C. Calhoun (Cambridge, MA: The MIT Press, [1992] 1996) (hereafter: HPSCal), 109-142; Keith Michael Baker, "Defining the Public Sphere in EighteenthCentury France," in HPSCal, 198; Geoff Eley, "Nations, Publics, and Political Cultures: Placing Habermas in the Nineteenth Century," in HPSCal, 309f.; Seyla Benhabib, "Models of Public Space," in HPSCal, 89-93.

${ }^{19}$ Dena Goodman, Public Sphere and Private Life: Toward a Synthesis of Current Historiographical Approaches to the Old Regime, "History and Teory", 31, no. 1 (Feb 1992): 14-20; Maciej Hułas, Decydować samemu. Sfera publiczna jako "locus" autonomii wedlug Jürgena Habermasa (Lublin: Wydawnictwo KUL, 2019), 251-253, 524.
} 
Habermas derives the normativity of the bourgeois public sphere from two individual claims that were viewed in the eighteenth century as self-evident and sacred: (1) the individual right to an unrestrained disposal of one's private property in free market commodity trade and social labor exchange; (2) the individual right to formulate one's opinion in the course of public debates through the engagement of cultivated minds and presenting it in the presence of others. Both claims ultimately come down to individual freedom that predisposes the person to an uninhibited self-determination. This is realized by means of an unrestricted disposition of one's intellectual capabilities and free possession of one's own property. Habermas takes the "bourgeois ideology" - anchored to the world that guarantees individual freedom to internalize universal human values (homme), and the freedom to dispose of one's private property acquired via the early liberal free market (Bürger-citoyen) - to be universal, even if it was historically set and culturally attached to the European Enlightenment. He asserts that what makes them universal is, firstly, the openness to cultural content that is inherent in human nature and shared by all, and, secondly, the systemic accessibility of a modern free market with its clearcut rules of participation applicable to everyone. Neither economically conditioned inequality of access to education which makes possible the proper comprehension of high culture, nor historically conditioned inequality of wealth distribution which excluded the majority of the eighteenth-century population from free market activities, contradict the inherent openness of human nature to involve itself in the products of high culture (knowledge, esthetics, morality), as well as the intrinsic openness of a free market to everyone with its codes of fair competition by engaging knowledge, discipline, fortune, etc. Any kind of interference on the part of an absolutist state in either of these claims, whether as interference in free market processes or censorship of the free press, was viewed as an invasion of man's individual freedom which was held as sacred and hence provoked opposition legitimized by codes of the new moral order of modernity. ${ }^{20}$ By making the bourgeois ethos a bulwark for protecting the normativity of an early liberal public sphere, Habermas reached for the emancipatory program of modernity which explains and provides moral justification for ordinary people's determination in asserting their fundamental freedoms as an inherent part of their humanity. By pointing to historical and civilizational coincidences that made up the circumstances for the bourgeois public sphere to emerge, Habermas delved into the postwar West German society in a quest to find repositories of the same self-awareness and the same instincts of self-determination that once helped the bourgeoisie to overcome its natural anxiety over forming an open counter-front that challenged state absolutisms. Habermas tried to instill in society the incentive for action, analogous to those which had

${ }^{20}$ Taylor, A Secluar Age, 159-168. 
inspired the eighteenth-century bourgeoisie in the struggle for individual freedoms, colonized by authoritarian powers. He strove to resuscitate the analogous self-defense reflex against new forms of authoritarianism that in its own manner continue to colonize various areas of the lifeworld, particularly in the realm of political self-determination.

Habermas's concept of the public sphere in its original formula comes into being in the acts of the bourgeoisie's non-conformity to the authoritarian policy of an absolutist state, striving to control key areas of civic autonomy, i.e. commodity exchange and social labor trade, as well as a free market of information and public opinion. That very reaction ideally epitomizes the selfdefense reflex manifested in open dissent in which individuals publicly defied the morally unjustified interference of external factors in the domain of sacred individual freedoms. In the era of the formation of the free market, the individual right that allowed one to operate freely in the realm of the economy by following individual market strategies, realized at one's own expense and risk, was viewed as the most obvious instance of privacy ${ }^{21}$ the violation of which triggered justified opposition. Habermas managed to capture that particular condition of psychological determination and recognized its role in the historical activation of those unique normative resources on which the public sphere feeds. The state's interference in the right of unrestrained rule over one's own property was viewed in the early liberal world as an invasion in the realm of individual freedoms famously portrayed by Locke: it impinged on the economic condition of the nuclear bourgeois family affecting its existence under the free market distribution of goods which was indispensable for living.

\section{THE POINT OF CONVERGENCE - THE PUBLIC SPHERE AND PRACTICAL INTERESTS}

The normativity of Habermas's public sphere, which emerged through the spontaneous reactions of ordinary people striving to protect their innate freedoms threatened by authoritarian absolutism, gains a significant boost on account of its convergence with practical interests - those which come up naturally in the midst of daily life. In his famous thesis on the joint union of knowledge and human interests, which is a hermeneutical key to correctly comprehending the logic of the public sphere, ${ }^{22}$ Habermas asserts that everything that absorbs cognitive attention and what is really worth knowing should

\footnotetext{
${ }^{21}$ Margaret R. Somers, "What's Political or Cultural about Political Culture and the Public Sphere? Toward an Historical Sociology of Concept Formation," Sociological Theory 13, no. 2 (1995): 126.

22 Richard Sennett, The Public Realm, "Quandt," available at: https://www.richardsennett.com/ site/senn/templates/general2.aspx?pageid $=16 \& \mathrm{cc}=\mathrm{gb}$; Peter Uwe Hohendahl, The Institution of Criticism (Ithaca: Cornell University Press, 1982), 271; Jäger, Öffentlichkeit und Parlamentarismus, 67.
} 
come out and be reflected in concrete existential needs. Therefore, practical needs delineate the very subject matter, the directions of human cognizance, and finally they are to be reflected in action. Habermas developed this thesis, which seems obvious prima facie, in the 1960s as a critical stance toward positivism. He claims that the positivist annexation of theory, which led to its confinement to the specialist taxonomy of methodological rigor, had distorted the primeval meaning of theory, as well as its original purpose - that is, to explain and interpret real problems which preoccupied people in their everyday lives. ${ }^{23}$ The implications of this thesis for the public sphere in general and its normative layer in particular can be identified as follows.

(1) Since an authentic public sphere always comes into being in spontaneous reactions through which ordinary people strive to protect their practical interests that are indispensable for their continued existence, it cannot, therefore, for the same reason serve as a testing arena for any so-called non-committal views. The issues which spontaneously enter the public debate are always practically defined, and they are neither neutral nor indifferent. Any authentic public sphere, notwithstanding different circumstances, constitutes a communication arena that is intended for "uncompromised realists": those who clearly understand the consequences of unresolved problematic situations in their everyday life. These are people determined to take up all possible, legally permitted actions that may result in a concrete solution that is essential to their vital interests. Making use of the public sphere as a means of testing new ideas might turn out to be too dear a lesson for them to afford. The public sphere is never the occasion for dealing with trivialities, but instead always seeks to resolve issues that are vital for everyday living.

(2) Practical interests vital for everyday life function as filters that protect the public sphere from an inundation of issues that do not have anything in common with provision for continued existence. It refers, firstly, to the aforementioned trivialities which, if included in public debate agendas, absorb participants' attention and leave less room for those problems that are of vital interest. Secondly, it is about protecting the component of critical rationality of those participating, which may be affected by the influx of information in the era of digital media. To refer to Lippmann, the large volume of news, regarding a variety of unrelated incidents, hijacks the recipients' attention and debilitates their capacity of grouping these disparate items into clusters of meaning. ${ }^{24}$ This

\footnotetext{
23 Jürgen Habermas, "Erkenntnis und Interesse," in Technik und Wissenschaft als "Ideologie" (Frankfurt: Suhrkamp, [1965] 1968), 146-151; David Held, Introduction to Critical Theory. Horkheimer to Habermas (Berkeley: University of California Press, 1980), 300; Andrzej Maciej Kaniowski, Filozofia spoleczna Jürgena Habermasa. W poszukiwaniu jedności teorii i praktyki (Warszawa: Kolegium Ortyckie, 1990), 176.

24 Walter Lippmann, Public Opinion. With a New Introduction by Michael Curtis, (New Brunswick/London: Transaction Publishers, [1922] 1998), 358.
} 
is indispensable in understanding the complexity of events that occur in the lifeworld. Practical interests are sobering to those who, by participating in public debates, make fundamental adjudications that are to be observed further by all as valid and legally binding. They work as stimuli of rational decision-making, particularly amid conditions of ubiquitous information influx and the recipients' impaired sensitivity, which prompts them to take a jaded view of many incidents whose seriousness is a cause for concern but go unnoticed because of the overabundance of news broadcast, e.g. reports on violence, accidents, humanitarian and natural disasters, as well as a variety of random incidents.

(3) The thesis on the inherent interdependence of knowledge and practical interests helps praxis to regain its original meaning which has been distorted by two universalisms that have organized and ruled everyday life in the modern era: market efficacy and instrumental rationality. ${ }^{25}$ In the systemic logic of those two universalisms, praxis has been equated with knowledge while action has been subordinated to the quickest and most rational profit capitalization, preferably via market. ${ }^{26}$ Praxis, meanwhile, goes beyond the narrow domain of market efficacy and instrumental rationalization. The range of forms of praxis realized in the modern world encompasses a diverse array of activities, many of which have little in common with markets and instrumental rationality, but nevertheless are indispensable for people in developing their personal integrity. Economic success, for instance, is not only a consequence of some short-term market strategies, as it may appear at first glance. It is, first and foremost, an outcome of actions carried out by autonomous subjects who stick to and follow the patterns set as a means of realizing their individual life plans. ${ }^{27}$ Regaining the original concept of praxis, freed from its instrumental market distortions, helps to reveal, among other things, the practical dimension of activities such as contemplation or reflection on the world of ideas, transcendence, art, etc. Practical interests that provide for continued existence are determining factors in public debates: they help participants regain the sense of being in charge of issues of utmost importance for long-term survival and all else that they face in the routine of their daily lives. In decent societies, i.e. those that do not pursue self-destructive ends, it is practical interests that delineate the directions in which demands are formulated; they impart logical cohesion into arguments being put forward; and they motivate to care for the substantive, ratio-critical component of public debates and the adjudications made therein.

\footnotetext{
${ }^{25}$ Immanuel Wallerstein, "Cultures in Conflict? Who we are? Who are the Others?," Journal of the Interdisciplinary Crossroads 1, no. 3 (2004): 505-521.

${ }^{26}$ Michael Burawoy, "For Public Sociology. Presidential Address," American Sociological Review 70 (2005): 11f.

${ }^{27}$ Gerald Dworkin, The Theory and Practice of Autonomy (Cambridge: Cambridge University Press, 1988), 10-13; John Christman, "Autonomy, History, and the Subject of Justice," Social Theory and Practice 33, no. 1 (2007): 1-6.
} 
Recall the two aforementioned sources of normativity on which Habermas's model of the public sphere rests: (1) protection of individual freedoms by making an uncompromising non-conformist demand for the inviolability of fundamental freedoms and negative rights of individual self-determination; and (2) the inseparable interdependence of knowledge and practical interests. Taken together, these bring Habermas's concept of the public sphere into line with those civilizational achievements whose proper functioning is essential for emancipation achieved by a life that lives up to one's own visions and aspirations.

Let us now track how Habermas's model of the public sphere was modified to respond to and accommodate further critiques and ascertain whether these modifications stand up to the original basis of normativity.

\section{NORMATIVITY OF THE PUBLIC SPHERE IN THE CRISES OF ADVANCED CAPITALISM}

Habermas made the first revision to his model of the public sphere in the early 1970s when dealing with the systemic crises of advanced capitalism defined as societal conditions of a state that is free-market oriented, democratic, and providing for the welfare of all. This revision, which has not resulted in any substantial alterations regarding the normativity of his public sphere, was, nevertheless, a harbinger that delineated the directions of future changes. In Habermas's view, the motivational crisis, which disrupts the socio-cultural, partial system, and the legitimation crisis, which upsets the partial system of politics, signal vital deficiencies in the functioning of the public sphere, and thereby clarify its normative premises that stand out when endangered. ${ }^{28}$

The proper functioning of the public sphere, considered by Habermas to be the way of societal emancipation, depends on how deeply it is ingrained in its normativity. However, the normativity derived from the bourgeois ethos ceases to function under the conditions of advanced capitalism in which the lifeworld is organized and ruled by social partial systems: economic, political, and sociocultural. The historical coincidence of the systems organizing and ruling the lifeworld on the one hand, and the comfortable living conditions provided by a welfare state on the other, prompted Habermas to introduce some changes into his original critical approach to democracy regarding its potential for securing ordinary people's political emancipation.

(1) Habermas sees the pretentiousness of formal democracy within the political partial system - which on the one hand provides the state in advanced capitalism with the essential minimum of its legitimation, while on the other

\footnotetext{
${ }^{28}$ Jürgen Habermas, Legitimationsprobleme im Spätkapitalismus (Frankfurt: Suhrkamp, [1973] 2015), 73.
} 
limits the political role of citizens to the right of a possible withdrawal of acclamations bringing about legitimation endorsing those who hold positions of political authority - as an instrumental misuse of those normative resources on which his model of the public sphere rests, and which the bourgeoisie had appropriated by standing up against the all-encompassing, absolutist state control, making these resources an integral part of its cultural ethos. Appropriating them required a price to be paid for the spontaneous and hazardous act of non-conformism by ordinary people directed against the overwhelming power of absolutism. Therefore, the very legacy of the public sphere must never be reduced to a minor issue of political praxis that is democratic in name only. Passivity, as an ordinary political condition of citizens in formal democracy of advanced capitalism, is defined by Habermas as a squandering of the emancipatory endeavors made by previous generations and as a regression into the world of a new absolutism. ${ }^{29}$

(2) The normativity of democracy and of the public sphere is derived from the unprecedented and unique marginal conditions of a specific temporality and civic culture, i.e. the modern Occident. In this sense, it is non-replicable even if it draws on the best resources of meaning available in the society of advanced capitalism, such as scientism, post-auratic art, and universal morality. (a) Scientific universalism, despite its all-encompassing nature, tends to break away from tangible problems of real life, which call for concrete solutions. (b) Post-auratic art turns out to be no match for the greatness of ethics and esthetics to the measure of "the Republic of Letters". (c) The generality of norms and autonomy as part of universal morality is not ingrained in social reality. The only way for the public sphere to retain its original normativity in advanced capitalism is by its continuation, and this may only be possible by rummaging into those areas of social life in which the repositories of the original normativity of the public sphere based on individual freedoms and negative rights are preserved. ${ }^{30}$

(3) When traditional axiologies linking the public sphere with its original normativity of individual freedoms and negative rights become obsolete, Habermas points to a new way of getting at the resources of the same normativity, i.e. consensus achieved within and through the specific terms of the ideal speech situation. Despite its utopian character, he is convinced that consensus can be attained, provided that it comes about spontaneously around vital existential interests. These vital existential interests and their translation into real existential conditions are what propel the automatism of the ideal speech situation and consensus.

\footnotetext{
${ }^{29}$ Ibid., 54-56.

${ }^{30}$ Ibid., $120-125$.
} 


\section{NORMATIVITY OF THE PUBLIC SPHERE IN THE WORLD OF PARTIAL SYSTEMS}

A formidable challenge for the normativity of Habermas's public sphere was Luhmann's famous thesis about the uselessness of collective identity for societal integration in a world organized and ruled by autopoietic partial systems. ${ }^{31}$ The fact that Habermas adopted a modified version of systems theory does not mean that he renounced everything that comprised the essence of his model of the public sphere, that is, individual emancipation of those participating through their capability of self-determination. The most substantial difficulty he encountered in realizing this vision, however, was the social, political, and economic conditions of the systemic world, which were entirely different from the transparent bourgeois order, with its clear-cut polarization of conflicting sides (society vs. the authoritarian state) representing diverse interests and clustered around different institutions of civil society: coffeehouses, salons, Tischgesellschaften, etc. Transferring the model of Habermas's public sphere from the bourgeois setting to a systemic one without losing any of its essence requires a maneuver which he describes as a shifting of normative sense. Such a shifting of normative sense is brought about by identifying those forms and those areas in which the public sphere's original normativity remains after being transferred from the bourgeois reality into the new conditions of the world organized and ruled by autopoietic partial systems. This is the world in which: (1) the integrating powers of traditional axiologies in society become obsolete; (2) privatism has weakened the sense of democracy and political participation; (3) technically specialized mechanisms of the political partial system has brought about civic torpor resulting from apathy and a sense of impotence, which in turn causes people to exclude themselves from participating in political decision-making. In a world organized and ruled by the partial systems, former demands made on the basis of traditional, bourgeois normative culture retain their essential layer when reformulated and remade on the basis of universal morality, which, in a pluralist society, replaces the traditional normative orientations. The weight of the former liberal bourgeois normativity finds, therefore, its new anchor in universal morality, which is not a derivative of traditional normative orientations, but rather is produced through correctable learning processes (Lernprozesse). Universal morality is manifested in generality, in the universality of equal opportunities to participate in communications which define identities and hence norms and values, as well as in the universality of humankind. The norms of universal morality are created in the individual identity projections of those participating in communication, that is, in their understanding of themselves in the broader perspective of the goals for which

\footnotetext{
${ }^{31}$ Niklas Luhmann, “Öffentliche Meinung,” Politische Vierteljahresschrift 11, no. 1 (1970): 11-16.
} 
they are striving, as well as their own self-perceptions. ${ }^{32}$ The normativity as derivative of universal morality is protected by Habermas's notion of communication that is discursive and experimental, drawing on reservoirs of rationality such as science, philosophy, art, and religion. ${ }^{33}$ Habermas does not treat communication as a rival to tradition. Rather, he perceives in it a moral vestige that remains after the potentials of traditional axiologies have expired. $\mathrm{He}$ asserts that communication carried out within the ideal speech situation guarantees continuity of those universal values that had been protected in the bourgeois era by individual freedoms and negative rights. The grassroots character of communication and its unofficial, diffuse, and apolitical nature (but with the ability to influence the decision-making process made in the realm of politics) are harbingers of the second unveiling of the public sphere, which Habermas introduced after the collapse of the Eastern bloc when new heightened demands for the idea of civil society heralded a new renaissance of the public sphere.

\section{NORMATIVITY OF THE PUBLIC SPHERE IN ZIVILGESELLSCHAFT}

In this new iteration of the public sphere, universal morality as a continuation of bourgeois normativity is anchored in the democratic structures of a constitutional state. In the normativity of radical democracy Habermas discerns new reservoirs of that normativity which provided legitimation to the public sphere since its very inception. He singles out several invariants typical of his concept of democracy, which he perceives as reservoirs that retain the original normativity of the public sphere and offer an outlet thereof. ${ }^{34}$

(1) The first invariant to which Habermas points is the thesis on the co-originality of private and public autonomy, derived from the individual subjective right. Habermas demonstrates how the Lockean notion of autonomy, viewed as negative self-determination, and the inborn condition of every human being (self-sufficiency) converge in a joint union with Rousseau's notion of autonomy, viewed as positive self-determination (self-rule). In this thesis, Habermas overcomes the traditional dichotomy of liberalism vs. republicanism, which converge and constitute a fusion of civic autonomy. ${ }^{35}$ In this paper I argue, that the critical mass in the public sphere formation exceeds in the moment in

\footnotetext{
32 Jürgen Habermas, "Können komplexe Gesellschaften eine vernünftige Identität ausbilden?," in Zur Rekonstruktion des historischen Materialismus (Frankfurt: Suhrkamp, 1976), 115-118.

${ }^{33}$ Jürgen Habermas, "Glauben und Wissen. Friedenspreisrede 2001," in Zeitdiagnosen. Zwölf Essays 1980-2001 (Frankfurt: Suhrkamp, 2003), 251-257.

34 Jürgen Habermas, Faktizität und Geltung. Beiträge zur Diskurstheorie des Rechtes und des demokratischen Rechtsstaats (Frankfurt: Suhrkamp, 1992), 12f.

${ }^{35}$ Ibid., 110-135; Jürgen Habermas, Die Einbeziehung des Anderen. Studien zur politischen Theorie (Frankfurt: Suhrkamp, 1996), 298f.
} 
which ordinary people (early bourgeoisie) cross the Rubicon of submission to the policy of an absolutist state. This statement may be confusing in a sense as it may give rise to the belief that Habermas derives his concept of the public sphere solely from negative rights. Individual autonomy anchored to fundamental freedoms, individual emancipatory interests and corresponding defensive rights endangered by morally unjustifiable policy of an absolutist state reflect perfectly the psychological condition of those bringing historically into being the first public sphere, it gives insight into the determination that ignites the public spirit in people, it consequently seems to mark the starting point of the public sphere as a first ring in the chain of its formation. In fact, however, both in his early and later works Habermas attempts to embed "negative" freedoms in the wider context of collective emancipation. The project of the early liberal public sphere that originates in private autonomy turned out to be successful thanks to the collective potentials of the critical deliberation in a search of consensus over what may best safeguard the collective welfare (public autonomy). The notion of private autonomy intertwined with the public one which Habermas expounded in detail in the 1990s is implicitly present in his concept of public sphere from its very beginning.

(2) The second invariant is the aforementioned communication accompanied by communicative power brought about in the collective agreement of will, which Habermas deems the source of just law. The communicative power springs from the psychological moment when public debate participants activate their natural communication abilities and from the intersubjectivity of everyday language and its diversity. The complexity of everyday language, along with its multifunctionality, is a reflection of the complexity and multifunctionality of the lifeworld, which opens the public sphere to the wide range of problems that ordinary people encounter in their daily routines. ${ }^{36}$

(3) The third invariant in which the original normativity of the public sphere is retained is the neutrality of ideas, which provides for and guarantees all participants in public debate common intelligibility under the condition of a pluralism of ideas. The neutrality of ideas enables the creation of a context of equal position for diverse stances in the public debate.

(4) The fourth invariant is the openness of the public sphere to the lifeworld, which signals the continuation of its inherent relationship with practical interests.

When the model of the public sphere developed by Habermas is transplanted from its original bourgeois setting to the reality of partial systems, it requires a new model of a civil society that preserves the original notion of civic autonomy in the world of partial systems. The bourgeois notion of civil society (Bürgergesellschaft) draws upon its Hegelian and Marxian conception, in which

\footnotetext{
${ }^{36}$ Habermas, Faktizität und Geltung, 183; Jürgen Habermas, "Hannah Arendts Begriff der Macht (1976)," in Philosophich-politische Profile. Erweiterte Ausgabe (Frankfurt: Suhrkamp, 1984), 228-231.
} 
autonomous individuals enjoy the freedom of decision-making and unrestrained acting to fulfill their existential needs, certain in the knowledge that no outside authority, that is to say, the absolutist state, would interfere into the realm of their personal freedom and violate their right to self-determination. The new concept of civil society no longer consists in autonomous individuals who issue a challenge to authoritarian powers in acts of protecting the realm of their personal freedom. Now, the challenge comes from grassroots associations composed of autonomous individuals who collectively form a unanimous stance resisting the lifeworld-colonizing powers of the partial systems. The civic autonomy in the new model of civil society is manifested no longer in individual unrestrained free-market interactions, but within the arena of free associations with every member having the equal right of freely expressing one's opinion. In both variants of civil society, the basic claim of individual freedoms and negative rights remains untouched. Habermas sees public opinion forged and expressed within associations as a new form of that particular act of selfdetermination which participants of the bourgeois public sphere had manifested in the conditions of an absolutist state. ${ }^{37}$

The civil society of the systemic world (Zivilgesellschaft) and the bourgeois society of the first modern public sphere (Bürgergesellschaft) share many common features. Both are independent of the systems of family, state, and economy. ${ }^{38}$ Both share the potential to mobilize ordinary people in challenging political organizations to reveal political processes and to generate and direct public opinion. ${ }^{39}$ Both share the potential for urging on and coordinating collective activities that have an impact on the course of state policy, demanding its transparency. ${ }^{40}$ Both are formed in demands for negative freedom, which furnish opportunities to participate in decision-making processes. Both create a room for positive freedom and solidarity within unofficial organizational structures. ${ }^{41}$ Both generate diverse forms of involvement in politics, economy, and culture - the diversity of associations corresponds to the diversity of the roles that ordinary people assume in society: citizens, consumers, family members, nation members, members of religious affiliations, etc. And finally, both variants of civil society create an arena for public debate in which all forms of privilege are excluded. ${ }^{42}$

\footnotetext{
${ }^{37}$ Habermas, Faktizität und Geltung, 443f., 449f.

${ }^{38}$ Heidrun Zinecker, "Zivilgesellschaft in Entwicklungsländer - konzeptionelle Überlegungen," Politische Vierteljahresschrift 46, no. 4 (2005): 529-533.

${ }^{39}$ Jens Steffek, "Zähmt zivilgesellschaftliche Partizipation die internationale Politik? Vom exekutivem zum partizipativem Multilateralismus," Leviathan 36, no. 1 (2008): 109f.

${ }^{40}$ Gunnar Schmidt, "Zivile Gesellschaft und öffentlicher Raum," Leviathan 23, no. 4 (1995): 565.

${ }^{41}$ Brett R. Wheeler, "Democratic Pluralism or Pluralist Democracy: Jürgen Habermas'ss Theory of Constitutional Morality and its Institutions," German Politics and Society 13, no. 3 (1995): 72f.

${ }^{42}$ Michael Walzer, Zivile Gesellschaft und amerikanische Demokratie, mit einer Einleitung von O. Kallscheuer (Berlin: Rotbuch Verlag, 1992), 66-79; Stefan May, “Zivilgesellschaft als
} 
The matrix of the civil society (Zivilgesellschaft) are associations which institutionalize public discourses that strive to solve problems that are of particular interest to the general public. The effective articulation of these problems in the public sphere - controlled by corporations and organized mass media, large agencies monitored by political parties and flooded with propaganda - requires a vehicle that will effectively introduce social interests into this world of corporations, agencies, and institutions of organized capital. These vehicles are associations.

\section{BIBLIOGRAPHY}

Adorno, Theodor W. Meinungsforschung und Öffentlichkeit (1964), Gesammelte Schrifen, Bd. 8: Soziologische Schrifen I, R. Tiedemann, unter Mitwirkung von G. Adorno, S. Buck-Morss, K. Schultz (eds.), Suhrkamp Verlag, Frankfurt/M [1972] 1990, 532-537.

Alexy, Robert. A Theory of Constitutional Rights. Oxford: Oxford University Press, [1986] 2010.

Allen, Amy. The Public Sphere: Ideology and/or Ideal?, „Political Theory”, Vol. 40, no. 6 (2012): 822-829.

Arendt, Hannah. The Human Condition. Introduction by Margaret Canovan. Chicago/London: The University of Chicago Press [1958] 1998.

Baker, Keith Michael. "Defining the Public Sphere in Eighteenth-Century France." In Habermas and the Public Sphere, edited by Craig Calhoun, 181-211. Cambridge, MA: The MIT Press, [1992] 1996.

Benhabib, Seyla. "Models of Public Space." In: Habermas and the Public Sphere, edited by Craig Calhoun, 73-98. Cambridge, MA: The MIT Press, [1992] 1996.

Burawoy, Michael. "For Public Sociology. Presidential Address." American Sociological Review 70 (2005): 4-28.

Calhoun, Craig. "The Public Sphere in the Field of Power", Social Science History, 34, no. 3 (Fall 2010): 301-335.

- The Roots of Radicalism. Tradition, the Public Sphere, and Early Nineteenth-Century Social Movements. Chicago: The University of Chicago Press 2012.

Christman, John. “Autonomy, History, and the Subject of Justice.” Social Theory and Practice 33, no. 1 (2007): 1-26.

Czyżewski, Marek. Öffentliche Kommunikation und Rechtsextremismus. Łódź: Wydawnictwo Uniwersytetu Łódzkiego, 2005.

Dewey, John, The Public and Its Problems, in The Later Works, 1925-1953, Vol. 2: 1925-1927, edited by J. A. Boydston, B. W. Walsh, Introduction, J. Gouinlock. Carbondale \& Edwardsville: Southern Illinois University Press, [1927] 1988.

Dworkin, Gerald. The Theory and Practice of Autonomy. Cambridge: Cambridge University Press, 1988.

Eisenstadt, Shmuel Noah. "Multiple Modernities.” Deadalus 129, no. 1 (2000): 1-29.

—. "Public Spheres and Civil Society in Selected Pre-Modern Societies: Some Comparative Observations." Comparative Sociology 5, no. 1 (2006): 1-31.

Demokratietheorie - Überlegungen zu einer aktuellen Debatte," Kritische Vierteljahresschrift für Gesetzgebung und Rechtswissenschaft (KritV) 80, no. 3 (1997): $318 \mathrm{f}$. 
Eley, Geoff. "Nations, Publics, and Political Cultures: Placing Habermas in the Nineteenth Century." In Habermas and the Public Sphere, edited by Craig Calhoun, 289-339. Cambridge, MA: The MIT Press, [1992] 1996.

Fleming, Marie. "Women and the 'Public Use of Reason'." Social Theory and Practice 19, no. 1 (Spring 1993): 27-50.

Fraser, Nancy. "Rethinking the Public Sphere." In Habermas and the Public Sphere, edited by Craig Calhoun, 109-142. Cambridge, MA: The MIT Press, [1992] 1996.

Goodman, Dena. Public Sphere and Private Life: Toward a Synthesis of Current Historiographical Approaches to the Old Regime, History and Teory, Vol. 31, no. 1, (Feb 1992): $1-20$.

Habermas Jürgen. Die Einbeziehung des Anderen. Studien zur politischen Theorie. Frankfurt: Suhrkamp, 1996.

—. "Erkenntnis und Interesse." In Technik und Wissenschaft als "Ideologie," 146-168. Frankfurt: Suhrkamp, [1965] 1968.

—. Faktizität und Geltung. Beiträge zur Diskurstheorie des Rechtes und des demokratischen Rechtsstaats. Frankfurt: Suhrkamp, 1992.

_. "Hannah Arendts Begriff der Macht (1976)." In Philosophich-politische Profile. Erweiterte Ausgabe, 223-248. Frankfurt: Suhrkamp, 1984.

—. "Können komplexe Gesellschaften eine vernünftige Identität ausbilden?" In Zur Rekonstruktion des historischen Materialismus, 92-126. Frankfurt: Suhrkamp, 1976.

—. Legitimationsprobleme im Spätkapitalismus. Frankfurt: Suhrkamp, [1973] 2015.

_. "Öffentlichkeit." In Staat und Politik. Das Fisher Lexikon, edited by E. Fraenkel and K. D. Bracher, 220-226. Frankfurt: Fischer Taschenbuch Verlag, [1957] 1976.

—. "The Public Sphere. An Encyclopedia Article" (1964), transl. Sara Lennox and Frank Lennox, New German Critique, no. 3 (Autumn 1974): 49-55.

- The Structural Transformation of the Public Sphere. An Inquiry into a Category of Bourgeois Society, translated by Thomas Burger with the assistance of Frederick Lawrence. Cambridge MA: The MIT Press [1962] 1991.

—. Strukturwandel der Öffentlichkeit. Untersuchungen zu einer Kategorie der bürgerlichen Gesellschaft. Neuwied: Luchterhand, [1962] 1990.

Habermas, Jürgen, Christoph Oehler, Ludwig von Friedeburg, and Friedrich Weltz. Student und Politik. Eine soziologische Untersuchung zum politischen Bewußtsein Frankfurter Studenten. Neuwied: Luchterhand Verlag, [1961] 1969.

Häberle, Peter. "Öffentlichkeit und Verfassung: Bemerkungen zur 3. Aufl. Von Jürgen Habermas, Strukturwandel der Öffentlichkeit (1968)", Zeitschrift für Politik, Neue Folge, Vol. 16, no. 2 (1969): 273-287.

Heidegger, Martin, Sein und Zeit. Tübingen: Max Niemeyer Verlag, [1926] 1967.

Held, David. Introduction to Critical Theory: Horkheimer to Habermas. Berkeley: University of California Press, 1980.

Hohendahl, Peter Uwe. The Institution of Criticism. Ithaca: Cornell University Press, 1982.

Honneth, Axel. Das Recht der Freiheit. Grundriß einer demokratischen Sittlichkeit. Berlin: Suhrkamp Verlag, 2015.

Hułas, Maciej. Decydować samemu. Sfera publiczna jako "locus” autonomii wedtug Jürgena Habermasa. Lublin: Wydawnictwo KUL, 2019.

Jäger, Wolfgang. Öffentlichkeit und Parlamentarismus. Eine Kritik an Jürgen Habermas. Stuttgart: Verlag W. Kohlhammer, 1973.

Kaniowski, Andrzej Maciej. Filozofia społeczna Jürgena Habermasa. W poszukiwaniu jedności teorii i praktyki. Warszawa: Kolegium Ortyckie, 1990.

Koselleck, Reinhart. Kritik und Krise. Eine Studie zur Pathogenese der bürgerlichen Welt. Freiburg/München: Suhrkamp [1959] 1973. 
Landes, Joan. Women and the Public Sphere in the Age of the French Revolution. Ithaca: Cornell University Press, 1988.

Lippmann, Walter. The Phantom Public. The Sequel to „Public Opinion”. New York: The Macmillan Company, 1930.

- Public Opinion. With a New Introduction by Michael Curtis. New Brunswick: Transaction Publishers, [1922] 1998.

Luhmann, Niklas. “Öffentliche Meinung.” Politische Vierteljahresschrift 11, no. 1 (1970): 2-28.

May, Stefan. "Zivilgesellschaft als Demokratietheorie - Überlegungen zu einer aktuellen Debatte." Kritische Vierteljahresschrift für Gesetzgebung und Rechtswissenschaft (KritV) 80, no. 3 (1997): 306-323.

Negt, Oskar, Kluge Alexander. Public Sphere and Experience. Toward an Analysis of the Bourgeois and Proletarian Public Sphere, foreward by M Hansen, transl. P. Labanyi, J. O. Daniel, A. Oksiloff. Minneapolis: The University of Minnesota Press, [1972] 1993.

Ronneberger, Franz. "Organisierte Interessen und öffentliche Meinungsbildung“", Soziale Welt, 15. Jahrg., H. 1 (1964): 36-49.

Schmidt, Gunnar. "Zivile Gesellschaft und öffentlicher Raum.” Leviathan 23, no. 4 (1995): 562579.

Schmitt, Carl. Die geistesgeschichtliche Lage des heutigen Parlamentarismus. Berlin: Duncker und Humbolt, [1923] 1961.

Sennett, Richard. The Public Realm. "Quandt." Available at: https://www.richardsennett.com/ site/senn/templates/general2.aspx?pageid $=16 \& \mathrm{cc}=\mathrm{gb}(21.08 .2019)$.

Somers, Margaret R. "What's Political or Cultural about Political Culture and the Public Sphere? Toward an Historical Sociology of Concept Formation.” Sociological Theory 13, no. 2 (1995): $113-144$.

Steffek, Jens. "Zähmt zivilgesellschaftliche Partizipation die internationale Politik? Vom exekutivem zum partizipativem Multilateralismus." Leviathan 36, no. 1 (2008): 105-122.

"Strukturwandel der Öffentlichkeit" von Jürgen Habermas. Michael Haller im Gespräch mit Hans Ulrich Probst. Radio SRF 2 Kultur. 14. März 2012.

Taylor, Charles. A Secular Age. Cambridge, MA: The Belknap Press of Harvard University Press, 2007.

Wallerstein, Immanuel. "Cultures in Conflict? Who we are? Who are the Others?" Journal of the Interdisciplinary Crossroads 1, no. 3 (2004): 505-521.

Walzer, Michael. Zivile Gesellschaft und amerikanische Demokratie, mit einer Einleitung von O. Kallscheuer. Berlin: Rotbuch Verlag, 1992.

Wheeler, Brett R. "Democratic Pluralism or Pluralist Democracy: Jürgen Habermas'ss Theory of Constitutional Morality and its Institutions." German Politics and Society 13, no. 3 (1995): 66-80.

Zinecker, Heidrun. "Zivilgesellschaft in Entwicklungsländer - konzeptionelle Überlegungen." Politische Vierteljahresschrift 46, no. 4 (2005): 527-551. 